ENTREPRENEURSHIP AND SUSTAINABILITY ISSUES

ISSN 2345-0282 (online) http://jssidoi.org/jesi/

2021 Volume 9 Number 4 (June)

http://doi.org/10.9770/jesi.2021.9.1(14)

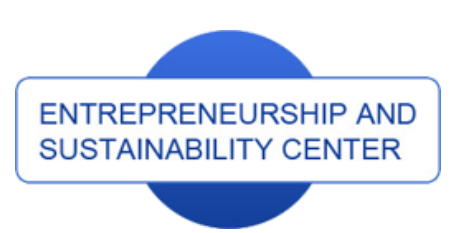

Publisher

http://jssidoi.org/esc/home
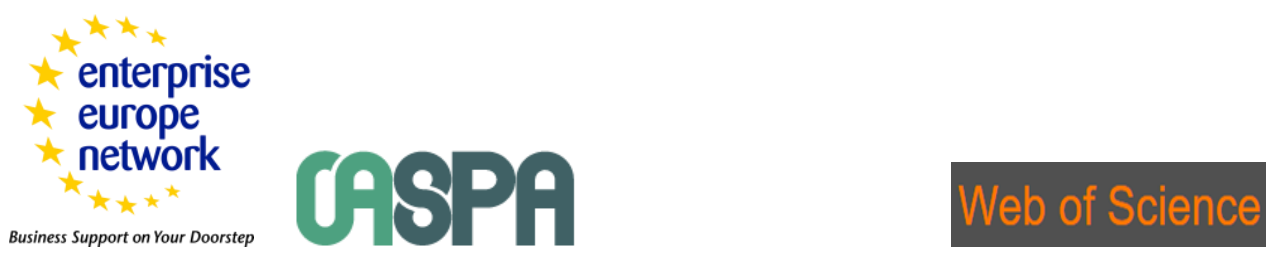

1) Clarivate

Analytics

\title{
MARKET DIFFERENTIATION POTENTIAL OF TRADITIONAL FOOD QUALITY LABELS: CONSUMER AND PRODUCER EXPECTATION*
}

\author{
Dominika Jakubowska \\ University of Warmia and Mazury in Olsztyn, M. Oczapowskiego 2 \\ 10-719 Olsztyn, Poland \\ E-mail: dominika.jakubowska@uwm.edu.pl
}

Received 15 June 2021; accepted 9 September 2021; published 30 September 2021

\begin{abstract}
In the last few decades more consumers are choosing food products based on their local and traditional attributes as well as environmental and sustainability issues. The food industry have introduced several strategies to guarantee product quality and sustainability (quality schemes and quality labelling). With their rising number it is hard for consumers to differentiate between them. The purpose of the paper is to investigate how consumers perceive traditional food quality labels and to confront consumer expectations with the producer's motivation to supply certificated traditional products. The analysis has been based on literature studies and empirical data ob-tained from qualitative research in 2020. Six focus groups were conducted, with 7-8 participants in each, among traditional food producers and consumers in Poland. As the results of this study show, the awareness of food quality labels in Poland is quite low. The study concluded that apart from providing producers with protection from food fraud and serving as a indicator of a given quality, the additional differentiation of traditional food quality labeling is clearly not obvious. Results add value to recent consumers' behavior knowledge by analyz-ing role of food quality labels in consumer decision-making and the possible mo-tives for producers that choose to feature them. These findings may be useful in developing effective educational and marketing activities in the traditional food sector.
\end{abstract}

Keywords: geographical indications, qualitative approach, labeling, buying decisions, suistainable consumption

Reference to this paper should be made as follows: Jakubowska, D. 2021. Market differentiation potential of traditional food quality labels: consumer and producer expectation. Entrepreneurship and Sustainability Issues, 9(1), 239-250. http://doi.org/10.9770/jesi.2021.9.1(14)

JEL Classifications: D91, M11, M31

\footnotetext{
* This research was supported by the project, which has received funding from the Polish National Science Center (NCN) udner the project Miniatura 3 (Grant Agreement Number 45051).
} 


\section{ENTREPRENEURSHIP AND SUSTAINABILITY ISSUES}

ISSN 2345-0282 (online) http://jssidoi.org/jesi/

2021 Volume 9 Number 4 (June)

http://doi.org/10.9770/jesi.2021.9.1(14)

\section{Introduction}

In the last few decades, a growing number of consumers choose food products based on their unique attributes related to local origin, traditional production method, as well as sustainability and ethical considerations (Zander et al., 2015, pp. 1506-1526). Those concerns have prompted various actions by both governmental institutions and food producers to help consumers choose suistainable and high-quality food (Resano et al., 2012, pp. 10641076), like for example quality scheme and quality labeling (Aprile et al., 2012, pp. 158-165). It has beed observed the development of sustainability related food labels aimed at reducing the information asymmetry between food practitioners and consumers regarding the sustainability impact on the food supply chain (Asioli et al., 2020).

Food quality labels are graphic symbols that can be placed on a product or its packaging, indicating that the product or the process complies with given standards and that this compliance has been certified (Velčovská, 2016, pp. 815-834). There are different types of certificates and quality labels that are placed on food products. In addition to international la-bels, each country has its own national and / or regional quality labels that are valid only in that country or region (Velčovská \& del Chiappa, 2015, pp. 647-658). The concept of quality labeling information re-ported in this article refers to specific traditional food quality labels such as "Jakość Tradycja", Traditional Specialty Guaranteed and "Culinary Heritage". Those labels differ from simple indications of origin in the sense that such quality schemes highlights the traditional aspects, like the way the product is made or its composition, without being linked to a specific geographical area. The registration of such products is subject to many laws and regulations designed to protect them from counterfeiting and unjustified misappropriation.

Despite the growing interest in the literature on consumer preferences for food quality labels, studies about consumer attitudes and producer motivations regarding food quality labels in different food categories are quite limited. For this reason, this study aims to fill the research gap by investigating how consumers perceive traditional food quality labels and to confront consumer expectations with the producer's motivation to supply certificated traditional product. It adds value to recent consumers' behaviour knowledge by analysing the role and function of food quality labels in consumer decision-making and the possible motives and benefits for producers that choose to feature them. An attempt has been made to answer the following research questions: whether and to what extent traditional food quality labeling is an appropriate way to differentiate food products in the market? More specifically, this research is focused on managerial and consumer's perspective of food quality labels assessed through determining whether consumers and producers put emphasis on the quality labels of traditional food prod-ucts and what are the determinants of their behaviours. The knowledge about the managerial and consumer's perspective of food quality labels, which represents the outcome of this study, will allow for adapting the educational and marketing strategies in the traditional food sector.

The focus is on traditional food sector in Poland, which is characterised by a large number of micro and small enterprises, whose market opportunities are related to changes in the behaviour of consumers in-terested in highquality food (Jakubowska \& Wierzejski, 2017, pp. 144-155). However, there is a problem with identifying these products. Insights into the potential for market differentiation through food quality labeling are provided and discussed using primary data collected in 2020 by means of interviews with six focus groups.

The paper is structured as follows: the first part includes an overview of the recent literature on food quality labels. Following this, the research method and the results of the empirical studies are presented. Conclusions and implications are then forwarded and, finally, study limitations and suggestions for future research are explained. 


\section{ENTREPRENEURSHIP AND SUSTAINABILITY ISSUES}

ISSN 2345-0282 (online) http://jssidoi.org/jesi/

2021 Volume 9 Number 4 (June)

http://doi.org/10.9770/jesi.2021.9.1(14)

\section{Theoretical background}

Food consumers make decisions daily, and choose from many alterna-tives (Bartosik-Purgat, 2018, pp. 123-142). Various determinants influence a particular consumer decision (Freitas Santos \& Cadima Ribeiro, 2012, pp. 294311 ), which is related to choosing the product/service that will bring consumers the benefit and satisfaction, and will be in accordance with consumer needs, values, preferences and financial capabilities (Pappas, 2016, pp. 92103). These are mostly based on the attributes of the product/service (e.g., label, price, taste, etc.). It can also be said that choices are made within specific attributes of alternatives in the decision-making proces (Czine et al., 2020, pp. 1-18). However, it is essential to know which characteristics are relevant and how important they are for consumers.

Food label information and logo certification may be important for communicating the existence of product attributes consumers' desire. The main intention of food labeling is to transfer information from the producer to the consumer (Van Boxstael et al., 2014, pp. 85-92 ) and to allow consumers to make informed choices (Lagerkvist, 2013, pp. 77-88). There are different kinds of quality labels. In contrast to general quality labels, which present all product quality characteristics, specific quality labels focus on particular quality characteristics ensuring the quality, safety, product origin, organic production (Kos Skubic et al., 2018, pp. 650-664). The EU traditional speciality guaranteed (TSG) label and its national equivalent highlight the traditional character of a product (Verbeke et al., 2012, pp. 213-229). Indications on food labels, such as quality marks, geographical indications or origin labels, may represent some value to consumers because they may be perceived as signaling a particular product specification (e.g., relating to authenticity) and quality level (Verbeke \& Roosen, 2009, pp. 2035). Through their signal value and visibility on product packages, such labels may provide a specific information cue that con-sumers search for during their shopping and purchasing decision pro-cesses. Consumers weigh the perceived value of a specific information cue on a label against other cues and product attributes as they make their decisions. Therefore food labels may represent a marketing tool and may influence consumers' perception of food quality (Czine et al., 2020, pp. 1-18). Quality expectations may affect consumer attitudes and behaviours related to food purchase (Grunert, 2005, pp. 369-391). For food quality labels to have value to consumers, they must be attended to and understood, what is often not fulfilled. Information cues relating to quality or traditional production method may be relatively difficult to interpret for consumers compared to more easily understood indications such as expiry or best-before dates (Grunert, 2005, pp. 369-391). From the consumer perspective, the perception of quality is often based on subjective evaluations rather than objective information such as product taste, origin, and appearance (Grunert \& Aachmann, 2016, pp. 178-187). In most cases, the interest of consumers in food knowledge is basic, hence they are unable to evaluate the objective di-mension of quality when making the purchase decision (Sadilek, 2019, pp. 2508-2523).Several studies confirmed that EU quality labels and other labels displaying information on the place of origin, specific production methods and composition may play an important role in willingness to pay, communicating credence attributes of food products and influence consumers' purchase decisions (de-Magistris \& Gracia, 2016, pp. 560-571; Erraach et al., 2014, pp.11-14; Schröck, 2014, pp. 1070-1091).

Summarizing findings from previous consumer studies it can be concluded that they are not unanimous with respect to whether food quality labels have a favourable impact on product evaluation by consumers. Therefore, the research is needed to diagnose the role and function of food quality labels in consumer decision-making. This justifies the advisability of the undertaken study presented in this manuscript. 


\section{ENTREPRENEURSHIP AND SUSTAINABILITY ISSUES}

ISSN 2345-0282 (online) http://jssidoi.org/jesi/

2021 Volume 9 Number 4 (June)

http://doi.org/10.9770/jesi.2021.9.1(14)

\section{Research methodology}

Previous studies on food quality labels have used different methodological approaches (cluster analysis, factor analysis, conjoint analysis) (Schröck, 2014, pp. 1070-1091; Balogh et al., 2016, pp. 176-184; de-Magistris \& Gracia, 2016, pp. 560-571; Sadilek, 2019, pp. 2508-2523). In this study a qualitative research design using structured focus group interviews was undertaken to collect the empirical material. This method is designed to be the primary choice in the case of insufficient knowledge about the research topic (Hudson, 2007). It was deemed to be the most appropriate as it allowed respondents' feelings and opinions to be discussed in order to reveal their motivations, prejudices, and attitudes (Proctor, 2005). A focus group is a small group of people which is gathered to engage in controlled discussions in order to elicit opinions about particular products or services. This approach is a specific tool for qualitative data collection, based on the dynamics of the group. Although the group pro-cess is one of its advantages, it might also result in an undesirable bias in the group (Sijtsema et al., 2013, pp.73-87).

Based on the preceding literature review of the role of food quality labels in consumer decision-making and the possible motives for producers that choose to feature them, two hypotheses were developed:

H 1. Consumers' perception of food quality labels is positive, despite their hypothesised low awareness.

$\mathrm{H}$ 2. Food producers put emphasis on the quality labels of their food products because of a conviction that it serves to differentiate their products from conventional food through positive product quality im-agery.

The data of this study were obtained from exploratory research methodology (qualitative research), based on small samples of both consumers and producers. The group discussions were led by an experienced moderator, based on a discussion guide that listed the issues to be covered. Six focus groups were held with seven to eight participants. In the first part of the study, focus group discussions were conducted with Polish consumers. Respondents were the main person responsible for food purchasing within their household. Consumers were only allowed to participate if they were responsible for food shopping and consumed traditional food products at least once a week. Table 1 shows the composition of the groups.

Table 1. Respondent's characteristics

\begin{tabular}{lll}
\hline & Olsztyn & Kraków \\
\hline Consumer research & & \\
$\begin{array}{l}\text { Focus group }(\mathrm{n}=4) \\
\text { Total respondents }(\mathrm{n}=30)\end{array}$ & $\begin{array}{l}\text { 8 persons: age 25-35 year } \\
\text { 8 persons: age }>35 \text { year }\end{array}$ & $\begin{array}{l}7 \text { persons: age 25-35 year } \\
7 \text { persons: age }>35 \text { year }\end{array}$ \\
\hline Producer research & & \\
Focus group $(\mathrm{n}=2)$ & Meat producers: 5 & Meat producers: 3 \\
Total respondents $(\mathrm{n}=15)$ & Cheese producers: 2 & Honey producers: 1 \\
& Beer producers: 1 & Juice producers: 1 \\
& & Bread, bakery producers: 2 \\
\hline
\end{tabular}

Source: Own research

Focus group interviews were also conducted to collect data for the producer survey. These interviews were conducted with Polish tradition-al food producers. Producers were selected for the survey if their production system fits into a traditional food initiative (they were members of local associations / groups promoting traditional production, they offered products with certificates confirming their tradition for sale). Producer's characteristics are shown in Table 1. 
All focus group sessions were audio-recorded and transcribed verbatim within 7 days of completing each session. It was explained to the respondents that all recordings would remain confidential, and information they provided would be used only for scientific analysis. Any information that was considered commercially sensitive or that would reveal informants' identities was removed.

\section{Results}

\section{Consumer perception of food quality labels}

When asked about the spontaneous knowledge of the labels appearing on food packaging, most consumers were not able to indicate any label identifying traditional products. During the conversation on the certification of traditional products, the respondents were handed a questionnaire with five quality labels appearing on food product packages (Table 2 ).

Table 2. Analysed quality labels appearing on food product packages

\begin{tabular}{|c|c|c|}
\hline 1. & & European Union organic food logo \\
\hline 2. & & "Jakość Tradycja/Quality Tradition" label \\
\hline 3. & & $\begin{array}{c}\text { Traditional Specialty Guaranteed (indicating a } \\
\text { product entered by the European Commission } \\
\text { into the Register of Traditional Specialties } \\
\text { Guaranteed) }\end{array}$ \\
\hline 4. & & $\begin{array}{l}\text { "Culinary Heritage" confirming affiliation to the } \\
\text { association of food producers and restaurant } \\
\text { owner from a given region manufacturing } \\
\text { regional food }\end{array}$ \\
\hline 5. & $\begin{array}{l}\text { POZNAJ DOBRA } \\
\text { ŻWWOŚć }\end{array}$ & $\begin{array}{c}\text { "Poznaj Dobrą Żywność/"Know Good Food" } \\
\text { label }\end{array}$ \\
\hline
\end{tabular}

The participants had a very limited knowledge about labels. They had difficulties to speak about them but they were sure that protecting the quality of food is important. The most recognisable label was the EU label of Traditional Specialty Guaranteed (TSG) - 76\% of the respondents correctly indicated its interpretation. The label of Culinary Heritage caused the most problems - it was recongised by only $40 \%$ of the respondents. A large disproportion can also be noticed between the correctness of the answers of younger and older respondents. The age group $>35$ years more often indicated correct answers to all assessed labels. The analysis of the results and statements made by the respondents during the subsequent group discussion, allows concluding that some labels were recognised by consumers, but not always enough to correctly read their meaning. 


\section{ENTREPRENEURSHIP AND SUSTAINABILITY ISSUES}

ISSN 2345-0282 (online) http://jssidoi.org/jesi/

2021 Volume 9 Number 4 (June)

http://doi.org/10.9770/jesi.2021.9.1(14)

The participants have no knowledge related to introducing labels showing the quality of the product but think that Polish traditional food should be protected by national or local legal regulations.

"It would be a good idea to have a certificate promoted by local governments to help identify these products on the local market."

"Legal product protection at the national and international level through certificates and quality labels is a way to protect the origin and quality of the product in order to prevent the traditional products from Poland being claimed by other countries".

Protecting traditional food is important for consumers to guarantee the origin of the product and the authenticity of it.

"Such a certificate provides information that the product has a long history and tradition of production, and thus a guaranteed quality".

The respondents also emphasized the importance of additional values of these products related to the guaranteed quality, safety or supporting local producers. Consumers agreed that these products reach higher prices on the market and a quality label may be important for their promotion.

"I am willing to pay more for a certified product, produced in the region, because I know that it combines good quality and taste"

"When purchasing a product directly from the manufacturer, the certificate does not matter much, because I know what source I am buying from. However, when I buy a product in a store or a restaurant, it allows me to distinguish it from others".

However, it was emphasized that for a certificate to be credible, the consumer must have confidence in the certification body. In the vast majority of cases, consumers do not know which institution is responsible for certification and how the certification process works.

The multitude of certificates present on the Polish market is also poorly received, which means that consumers stop treating them as a distinguishing feature of quality. The respondents emphasised that the presence of quality labels on food packaging informs them that a given product is characterised by a certain level of quality, but it is rather an auxiliary element and not decisive for its purchase.

"Everything has a certificate. Due to the fact that it is overused, I do not pay attention to these labels."

The increasingly common practice among large producers / retail chains in Poland to create their own certificates confirming the quality of products causes that consumers approach them with a reservation.

Consumers believed that traditional products should be properly labeled to support their purchasing decisions and the local economy to protect and develop traditional food production. At the same time, the respondents pointed to the need to preserve the traditional values of the products to avoid their industrialization, as well as to build a consumer-producer relationship to strengthen the credibility of using food quality labels. 


\section{ENTREPRENEURSHIP AND SUSTAINABILITY ISSUES}

ISSN 2345-0282 (online) http://jssidoi.org/jesi/

2021 Volume 9 Number 4 (June)

http://doi.org/10.9770/jesi.2021.9.1(14)

\section{Producer expectations related to food quality labels}

According to the producers of traditional food in Poland, the importance of certificates and quality labels of food products has significantly devalued over the years. There is no certificate or quality label, which would be universally recognised among consumers, and whose use would be perceived by producers as an ennoblement. Currently, the vast number of labels and certificates awarded not only at the national level, but also at the regional and local levels, diminished their recognizability among customers, and thus their real informative value.

"People don not respond to these labels. There are so many of them and on so many different products that the consumer does not recognise them and does not identify himself with them. In my case, the cost of maintaining a labale does not translate into the final product, and into its prestige"

There were also different approaches among manufacturers of products bearing certificates and quality labels. They were representatives of small- and medium-sized enterprises. They declared that their company benefited from the certification of its products, although they admitted that these benefits are difficult to attribute to food quality labels alone.

"It is difficult to measure directly how food quality labels affect our gains. There are many other factors."

"I perceive food quality labels as important information for consumers, which should translate into increased sales of products. However, it is difficult to directly relate these results to their costs. "

The producers suggested that having food quality labels could bring tangible business benefits, including increased sales, premium pricing, and the financial benefits of customer loyalty.

"We are a company that is recognised and trusted by consumers and we strive to maintain this trust. Food quality labels confirm what consumers already know about us. This trust leads to loyalty and can lead to financial gain in the future."

The producers also pointed to the benefits of product differentiation and providing additional value to consumers. They explained that food quality labels can be an element differentiating products available on the market.

"As a result of globalization and increasing competition on the market, it becomes more and more difficult to distinguish a product. For example, it is difficult to differentiate meat solely on the basis of its organoleptic properties. This can be achieved in other ways, including through food quality labels or price."

The surveyed producers also emphasised that the certification process is often very expensive, which in many cases blocks the way for small, sole proprietorships or family businesses. The respondents also pointed to the fact that the criteria adopted in Poland enabling manufacturers to undergo the certification process are so broad that they cover a too wide group of entrepreneurs. According to the respondents, a different approach should be adopted - to a greater extent promoting small, local production and entities based on traditional production methods. As it was argued, as a result of the legal solutions existing in Poland, truly traditional producers are placed on an equal footing with the big players in the food industry, which, according to the participants of the study, is unfair. 


\section{ENTREPRENEURSHIP AND SUSTAINABILITY ISSUES}

ISSN 2345-0282 (online) http://jssidoi.org/jesi/

2021 Volume 9 Number 4 (June)

http://doi.org/10.9770/jesi.2021.9.1(14)

The issues mentioned above are the reason why a significant part of manufacturers of traditional products resigns from the effort of applying for certification. The resignation from the certification process is also influenced by the strong conviction of small producers about the need to invest resources and effort in individual relations with the clients, convincing them to their products through direct contact. The respondents claimed that they themselves become a guarantor of the tradition of their products for consumers, with a greater impact than any quality label or certificate anonymous for the buyers.

"In our scale of operations, this certification is not so important, because our customers, our market where we distribute our products, already recognise us as producers (...) In the micro scale, this customer is more valuable than the certificate."

During discussions with producers, there was often a postulate to restore the meaning of certificates so that they could really serve consumers when making decisions about purchasing traditional products. To this end, it was proposed to limit the number of certificates and to encourage local governments to promote their own certification / identification systems for traditional products, created in cooperation with manufacturers and recognised by consumers.

"In my case, it is nice to have this "Spichlerz Koronny" label, being a local [label] for 5 neighboring municipalities around Krakow, rather than a national or European certificate, where most people will not know who I am, and where I am from."

$\mathrm{H} 1$ and $\mathrm{H} 2$ should be accepted in view of the following findings. Consumers view positively food quality labels, despite their low awareness. They put emphasis on the quality labels of traditional food products because of a belief that it will add quality value of products that feature these associations. However, the research results indicate that a traditional food quality label does not seem to be really important for Polish buyers. Given the limited consumer awareness, this result suggests that the traditional food quality label scheme may be problematic as a tool for product differentiation from conventional food.

\section{Discussion}

The analysis of literature indicated that there is growing interest in traditional food among consumers and food producers (Barska \& Wojciechowska-Solis, 2018 pp. 1994-2004). The research question the author of this study tried to answer was: whether and to what extent traditional food quality labeling is an appropriate way to differentiate food products in the market?

Based the studies presented in the paper and their results, it could be concluded that the differentiation potential of food quality labels in Poland is quite limited. The knowledge of traditional food quality labels among buyers of traditional food in Poland is negligible. They are not treated by the Polish consumers as unambiguous identifiers of high-quality or traditional food products. No food quality label was spontaneously mentioned by Polish respondents, which suggests that consumers are not able to fully use the labels in their purchase decisions. However, analysing the results obtained in this study, it can be said that officially certified food quality labels ensure consumers that producers have adopted methods resulting in high quality food products. Thus, they enhance the credibility of a product among consumers. The value added to food products by quality labels increases with consumer demand for high quality and authentic products. However, one should not forget that the knowledge of traditional food quality labels among buyers of traditional food in Poland is negligible. Therefore, an efficient marketing strategy is required to familiarise consumers with such products and ensure that they will keep buying afterwards. 


\section{ENTREPRENEURSHIP AND SUSTAINABILITY ISSUES}

ISSN 2345-0282 (online) http://jssidoi.org/jesi/

2021 Volume 9 Number 4 (June)

http://doi.org/10.9770/jesi.2021.9.1(14)

These results confirm the findings of previous studies conducted by other researchers. In general, direct indications of quality, including mandatory information cues such as best-before dates and species names, are found to be more appealing to consumers than food quality labeling (Verbeke \& Roosen, 2009, pp. 20-35). The different studies yield the conclusion that the number of food quality labels is perceived as very high and confusing for consumers (Sadilek, 2019, pp. 2508-2523), which may cause the label an unimportant attribute (Schröck, 2014, pp. 1070-1091; Rousseau, 2015, pp. 92-100).

The analysis of literature indicated that the influence of food quality labeling on consumer preferences varies between products and countries (Grunert \& Aachmann, 2016, pp. 178-187). For example, for Greek consumers of upper social and income groups the appearance of a quality label on Zagora apples was more important than the product's price (Fotopoulus \& Krystallis, 2003, pp 1350-1374). In Spain the price and PDO label (Protected Designation of Origin) were the attributes that most affected consumer preferences for olive oil (Erraach et al., 2014, pp.11-14).

Some surveys have also revealed differences in consumer perception of specific food product categories. For example, in Italy the role of the food quality label was stronger for olive oil than for oranges and grapes (Scarpa et al., 2005, pp.329-349).

The literature underlined that personal characteristics, such as age, gender, income level and education matters when evaluating food products with different quality labels (Krystallis \& Ness, 2005, pp. 62-91; Fotopoulus \& Kristallis, 2003, pp 1350-1374; Kos Skubic et al., 2018, pp. 650-664). Female and older respondents were willing to pay more for quality labelled products (de-Magistris \& Gracia, 2016, pp. 560-571).

These study findings confirm that food labels containing information on the traditional production can be an aid to distinguishing quality. However, in Poland this aid seems to be not supportive enough, especially among consumers who are less familiar with food quality policies. The study concluded that apart from providing producers with protection from food fraud and serving as an indicator of a given quality, the additional differentiation and marketing potential of traditional food quality labeling is clearly not obvious. The findings suggest that direct consumer interest in traditional food quality labeling in a country like Poland, with little experience with quality labels, cannot be taken for granted.

\section{Conclusions}

This paper reports insights from exploratory research focusing on consumer and producer expectations about traditional food quality labels in Poland. The producers pointed to the low level of consumer awareness of the labeling of traditional food products. The results of the consumer survey confirm that the buyers' orientation in this matter is negligible. Therefore, a large part of the surveyed manufacturers questioned the sense of certification, claiming that its business effects are disproportionate to the benefits obtained.

This indicates the need to create a single label promoting traditional products throughout the country, the dissemination and support of which would be the responsibility of producers and institutions at the local or central level. However, taking into account that most of the producers of traditional food in Poland are small family businesses, often without capital reserves, it should be ensured that the participation in the certification program depends exclusively on the entity meeting the qualification criteria, and not on its financial capabilities.

As far as practical implications are considered, the findings imply that traditional food producers should design marketing strategies that would project quality labels for traditional food to effectively communicate product quality attributes, thus reduce information asymmetry. This implies the need for companies and local authorities in Poland to improve the level of consumer knowledge of food quality labels. This could help consumers to 


\section{ENTREPRENEURSHIP AND SUSTAINABILITY ISSUES}

ISSN 2345-0282 (online) http://jssidoi.org/jesi/

2021 Volume 9 Number 4 (June)

http://doi.org/10.9770/jesi.2021.9.1(14)

improve their knowledge about certification labels and, consequently, their acceptance and intention to purchase them.

Although these results suggest practical implications for companies, there are some limitations that are worth highlighting. The main limitations of this research are linked to the qualitative nature of the research method that was used. As a result, the findings are preliminary and cannot be generalised to the entire population. Instead, these insights form grounds for developing hypotheses for further quantitative research with large samples of consumers and producers.

Further research, using quantitative methods, should be implemented to investigate the findings on the traditional food market in Poland. The results presented here only considered qualitative consumer data, without focusing on potential differences between different consumer segments and without concentrating on particular niche markets. Therefore, investigating particularities of specific market segments is recommended. Relations between consumer attitudes and producer motivations regarding food quality labels in different food categories were not tested in this research due to its exploratory nature. Therefore, there is a need to further investigate the role and importance of food quality labels for different groups of consumers and specific categories of food. It would also be appropriate for future research to measure the benefits and costs that food producers perceive.

\section{References}

Aprile, M.C., Caputo, V., Nayga, R.M. (2012). Consumers' valuation of food quality labels. International Journal of Consumer Studies, 36(2). doi: 10.1111/j.1470-6431.2011.01092.x

Asioli, D., Aschemann-Witzel, J., \& Jr., R. M. N. (2020). Sustainability-Related Food Labels. Annual Review of Resource Economics, 12(1). doi: 10.1146/annurev-resource-100518-094103

Balogh, P., Bekesi, D., Gorton, M., Popp, J. and Lengyel, P. (2016). Consumer will-ingness to pay for traditional food products. Food Policy, 61(2). doi: 10.1016/J.FOODPOL.2016.03.005

Barska, A., Wojciechowska-Solis, J. (2018). Traditional and regional food as seen by consumers - research results: the case of Poland. British Food Journal, 120 (9). doi: 10.1108/BFJ-01-2018-0054

Bartosik-Purgat, M. (2018). Country of origin as a determinant of young Europeans` buying attitudes — marketing implications. Oeconomia Copernicana, 9(1), doi: 10.24136/oc.2018.007

Czine, P., Török, A., Pető K., Horváth P., Balogh P. (2020) The Impact of the Food Labeling and Other Factors on Consumer Preferences Using Discrete Choice Modeling-The Example of Traditional Pork Sausage. Nutrients, 12(6):1768. doi: 10.3390/nu12061768

de-Magistris, T. and Gracia, A. (2016). Consumers' willingness to pay for light, or-ganic and PDO cheese: an experimental auction approach. British Food Journal, 118(3), doi: 10.1108/BFJ-09-2015-0322

Erraach, Y., Sayadi, A., Gomez, A.C. and Parra-Lopez, C. (2014). Consumer stated preferences towards protected designation of origin labels in a traditional olive-oil-producing country: the case of Spain. New Medit, 4(1)

Fotopoulus, C., Krystallis, A. (2003). Quality labels as a marketing advantage: the case of PDO Zagora apples in the Greek market. European Journal of Marketing, 37(10), doi: 10.1108/03090560310487149

Freitas Santos, J., \& Cadima Ribeiro, J. (2012). The Portuguese online wine buying consumer: characteristics, motivations and behaviour. EuroMed Journal of Business, 7(3). 


\section{ENTREPRENEURSHIP AND SUSTAINABILITY ISSUES}

ISSN 2345-0282 (online) http://jssidoi.org/jesi/

2021 Volume 9 Number 4 (June)

http://doi.org/10.9770/jesi.2021.9.1(14)

Grunert, K.G. (2005). Food quality and safety: consumer perception and demand. European Review of Agricultural Economics, 32, doi: 10.1093/eurrag/jbi011

Grunert, K.G., Aachmann, K. (2016). Consumer reactions to the use of EU quality labels on food products: A review of the literature. Food Control, 59, doi: 10.1016/j.foodcont.2015.05.021

Hudson, D, (2007). Agricultural markets and prices. Blackwell Publishing, Oxford Acknowledgments.

Jakubowska, D., Wierzejski, T. (2018). Evaluation of market concentration of regional and traditional food production in Poland and European Union Countries. Zeszyty Naukowe Szkoły Głównej Gospodarstwa Wiejskiego w Warszawie, Problemy Rolnictwa Światowego, 18(3). doi: 10.22630/PRS.2018.18.3.73

Kos Skubic, M., Erjavec, K., Klopčič M. (2018). Consumer preferences regarding national and EU quality labels for cheese, ham and hone. The case of Slovenia. British Food Journal, 120(3), doi: 10.1108/BFJ-04-2017-0236

Krystallis, A., Ness, M. (2005). Consumer preferences for quality foods from a South European perspective: a conjoint implementation on Greek olive oil. In-ternational Food and Agribusiness Management Review, 8(1)

Lagerkvist, C.J. (2013). Consumer preferences for food labelling attributes: comparing direct ranking and best-worst scaling for measurement of attribute importance, preference intensity and attribute dominance. Food Quality and Preference, 29(2).

doi: 10.1016/j.foodqual.2013.02.005

Pappas, N. (2016). Marketing strategies, perceived risks, and consumer trust in online buying behaviour. Journal of Retailing and Consumer Services, 29. doi: 10.1016/j.jretconser.2015.11.007

Proctor, T. (2005). Essentials of Marketing Research, Fourth Edition, Pearson Edu-cation Ltd.

Resano, H., Sanjuan, A.I., Albisu, L.M. (2007). Consumers' acceptability of cured ham in Spain and the influence of information. Food Quality and Preference, 18 (8), doi: 10.1016/j.foodqual.2007.05.002

Rousseau, S. (2015). The role of organic and fair trade labels when choosing choco-late. Food Quality and Preference, 44, doi: 10.1016/j.foodqual.2015.04.002

Sadílek, T. (2019). Consumer preferences regarding food quality labels: the case of Czechia. British Food Journal, 121(10). doi: 10.1108/BFJ-03-2019-0150

Scarpa, R., Philippidis, G. and Spalatro, F. (2005). Product-country images and pref-erence heterogeneity for mediterranean food products: a discrete choice framework. Agribusiness, 21(3), doi: 10.1002/agr.20051

Schröck, R. (2014). Valuing country of origin and organic claim. British Food Jour-nal, 116(7), doi: 10.1108/BFJ-12-2012-0308.

Sijtsema, S.J., Zimmermann, K.L., Cvetković M., Mora C., Martine Zaouche-Laniau M., (2013). Assessing Fruit Perception Using Focus Groups. In D. Barjolle, M. Gorton, J. Miloševic -Dordevic, Ž. Stojanovic (Eds) Food Consumer. Theories, Methods and Application to the Western Balkans. Springer Dor-drecht Heidelberg New York London.

Stewart, D.W., Shamdasini, P.N. (1990). Focus Groups: Theory and Practice. New-bury Park, CA: Sage.

Van Boxstael, S., Devlieghere, F., Berkvens, D., Vermeulen, A., Uyttendaele, M. (2014). Understanding and attitude regarding the shelf life labels and dates on pre-packed food products by Belgian consumers. Food Control, 37. doi: 10.1016/j.foodcont.2013.08.043

Velčovská, S. (2016). Food quality labels from the producers' perspective. Journal of Central European Agriculture, 17(3). doi: 10.5513/JCEA01/17.3.1779

Velčovská, Š., del Chiappa, G. (2015). Food quality labels: awareness and willing-ness to pay in the context of the Czech Republic. Acta Universitatis Agriculturae et Silviculturae Mendelianae Brunensis, 63(2).

Verbeke, W., Pieniak, Z., Guerrero, L., Hersleth, M. (2012). Consumer awareness and attitudinal determinants of European Union quality label use on traditional foods. Bio-Based and Applied Economics, 1(2), doi: 10.13128/BAE-10558 


\section{ENTREPRENEURSHIP AND SUSTAINABILITY ISSUES}

ISSN 2345-0282 (online) http://jssidoi.org/jesi/

2021 Volume 9 Number 4 (June)

http://doi.org/10.9770/jesi.2021.9.1(14)

Verbeke, W., Roosen, J. (2009). Market differentiation potential of country-of-origin, quality and traceability labeling. Estey Centre Journal of International Law and Trade Policy, 10(1). doi: 10.22004/ag.econ.48790

Zander, K., Padel, S., Zanoli, R. (2015). EU organic logo and its perception by con-sumers. British Food Journal, 117(5). doi: 10.1108/BFJ-08-2014-0298.9.

\section{Acknowledgements}

This research was supported by the project, which has received funding from the Polish National Science Center (NCN) udner the project Miniatura 3 (Grant Agreement Number 45051).

Dominika JAKUBOWSKA is the Assistant Professor at Department of Market and Consumption, University of Warmia and Mazury, Poland. She has long been involved in the research of consumer behavior. Research interests: food choice, consumer decision-making, suistainable consumption.

ORCID ID: orcid.org/0000-0002-2797-9680

Make your research more visible, join the Twitter account of ENTREPRENEURSHIP AND SUSTAINABILITY ISSUES: @Entrepr69728810

Copyright (C) 2021 by author(s) and VsI Entrepreneurship and Sustainability Center

This work is licensed under the Creative Commons Attribution International License (CC BY).

http://creativecommons.org/licenses/by/4.0/

(c) (i) Open Access 